\title{
LANGKAH STRATEGIS MENGHADAPI SITUASI EKONOMI-POLITIK INDONESIA
}

\author{
Edy Suandi Hamid \\ Fakultas Ekonomi Universitas Islam Indonesia (UII) \\ edysuandi@yahoo.com
}

\section{Abstract}

The importance of strategic policy in the area of political economy in among the significant factors determining the economic wellbeing of the society. The intervening variables that comes from various aspects within the country or global environment as well, also contribute to creation of economic stability. There are political flaws and global forces to be considered. Among political flaws in there are acute corruption mentality and high cost political process, whereas among global forces are WTO and various funding institutions. The both aspects have led to the difficulty in maintaining a good economic wellbeing of the country. Amidst such condition, the importance of local culture should be properly recognized for the creation of a betel political situation. Again, a careful negotiation should also be initiated to persuade global forces in order. that global policies may not burdening domestic economic progress.

\section{Pendahuluan}

Perkembangan lingkungan strategik dalam kehidupan berbangsa saat ini dinilai kurang mendukung bagi upaya percepatan mewujudkan kesejahteraan masyarakat. Hal ini antara lain ditandai oleh makin lunturnya kepercayaan rakyat terhadap aparatur pemerintah dan lembaga penegak hukum. Masyarakat tentu saja memiliki sejumlah alasan untuk kurang percaya kepada penyelenggara negara maupun penegak hukum. Maraknya malpraktik kekuasaan dan pelanggaran hukum oleh aparat menjadi salah satunya. Akibatnya kemudian pelayanan publik sebagai prinsip utama pemerintahan tidak berjalan dengan maksimal.Beragam alasan dapat diajukan untuk menjelaskan mengapa aparatur pemerintahan dan penegak hukum gagal melaksanakan fungsinya secara maksimal. Salah satunya adalah lunturnya etika dalam diri para aparatur pemerintah dan penegak hukum.

Lunturnya etika ini dapat dilihat dari mudahnya mereka yang memegang amanah kekuasaan untuk melakukan pelanggaran demi keuntungan jangka pendek. Para pemegang amanah di negeri ini senantiasa disumpah di awal masa jabatannya dengan nama agama dan keyakinannya. Selain itu, kode etik yang menjadi pedoman dalam pelaksanaan tugasnya pun didiseminasikan melalui pendidikan dan latihan, serta kegiatan lainnya. Namun seiring berjalannya waktu dan disebabkan sejumlah godaan, sumpah dan kode etik tersebut sedikit demi sedikit luntur, sehingga pelayanan kepada publik sebagai tujuan utama penyelenggaraan negara dengan sendirinya tergusur oleh kepentingan memperkaya diri dan keluarga.

Etika dan moralitas sering dimaknai sama dan hal ini memang wajar dan tidak salah. Terdapat dua pengertian etika, yaitu pertama berasal dari bahasa Yunani ethos yang dalam bentuk jamaknya ta etha bermakna adat istiadat atau kebjasaan. Etika dalam kerangka ini berhubungan dengan kebiasaan yang baik pada individu maupun masyarakat yang kemudian diwariskan secara turun temurun dan terpola dalam perilaku sebagai kebiasaan. Pengertian kedua menekankan etika sebagai filsafat moral atau ilmu yang membahas dan mengkaji nilai dan norma yang diberikan oleh moralitas atau etika (Keraf 1998:14 dalam Bawono 2008). 
Dalam kaitannya dengan etika organisasi pemerintahan, perlu disadari bahwa pelayanan merupakan prinsip utama yang dengannya aparatus diharapkan memiliki semangat melayani (a spirit of public service) dan mampu menjadi mitra bagi masyarakat (partner of society). Hal ini dapat diwujudkan dengan transformasi sikap untuk membudayakan kode etik di lingkungan pemerintahan. Aparatur pemerintahan yang terlibat dalam proses ini dituntut mampu membangun sikap terbuka, transparan, dan akuntabel (Mustopadidjaja, 1997 dalam Sudjana, 2006).

Lunturnya etika pemerintahan sekaligus dapat menjelaskan hilangnya jati diri bangsa berupa maraknya anarkisme, konflik horisontal, korupsi, kerusakan lingkungan dan lainnya. Dalam konteks ini akar budaya dan etika berbangsa,termasuk dalam kehidupan politik, layak untuk dirujuk sebagai pemecah masalah (Ginting, 2008). Etika politik sebagai bagian dari penyelenggaraan pemerintah pada dasarnya diarahkan untuk mengarahkan kehidupan ke arah yang lebih baik, bersama dan untuk orang lain, dalam rangka memperluas kebebasan dan membangun institusi-institusi yang adil (Mahfud, 2008). Hal ini mengindikasikan Makalah singkat ini dimaksudkan untuk melihat bagaimana kondisi lingkungan strategik nasional saat ini dikaitkan dengan etika berbangsa dan risiko disintegrasi yang dapat terjadi jika berbagai masalah dalam lingkungan strategik tersebut tidak diatasi.

\section{Lingkungan Strategik dan Integritas Bangsa}

Lingkungan strategik nasional saat ini dalam banyak hal menyiratkan sejumlah permasalahan serius yang harus mendapat perhatian kita semua. Masalah-masalah ini ada yang berkaitan dengan dunia politik, ekonomi, sosial, pendidikan, dan lainnya. Berbagai masalah ini bersifat saling terkait dan saling mempengaruhi serta berdampak pada etika dan integritas bangsa secara umum. Politik nasional saat ini seolah telah menjadi 'industri' dengan para politisi sebagai 'industriawan' yang bermain di dalamnya. Wujud dari industri politik ini dapat dengan mudah kita lihat dari masifnya praktek korupsi yang terjadi di dunia politik dan melibatkan politisi.

Dengan logika industri, para pemegang kekuasaan seolah berlomba menghasilkan 'laba'. yang diperas dari uang rakyat untuk menutupi 'modal' politik yang telah dikeluarkan sebagai 'investasi' awal sebelum menjadi pejabat publik, pemegang kekuasaan. Tidak hanya itu, watak industri.yang merasa lebih nyaman dan aman serta langgeng dengan bentuk pasar yang 'monopolis' pun juga diadopsi, sehingga yang terjadi adalah upaya memperkaya diri, kroni, sahabat, kolega, dan teman ideologis. Tujuannya tidak lain adalah untuk menjamin keberlangsungan 'industri' politik itu sendiri. Akibatnya korupsi terjadi secara berjamaah dan berantai, sehingga sebuah kasus korupsi jika ditelusuri lebih jauh akan membuka tabir dari sekelompok pelaku, bukan hanya orang per orang.

Dampaknya kemudian adalah pada keterbatasan pemerintah di masa Reformasi ini untuk menunjukkan kemampuannya dalam membangun perekonomian yang tangguh demi tujuan mencapai kesejahteraan rakyat. Hasil studi Kaufmann, Kraay, dan Mastruzzi (2008),yang dirangkum oleh Bank Dunia dalam The Worldwide Governance Indicators (WGI) project, yang meneliti indikator tata pamong pemerintah menunjukkan bahwa masa Reformasi dengan semangat demokratisasi ternyata belum memberikan hasil maksimal. Hasil dari studi terhadap beberapa indikator yang melibatkan data dari sekitar rata-rata 194 negara untuk setiap indikatornya ini menunjukkan bahwa proses demokrasi Indonesia setelah Reformasi berlangsung belum menunjukkan hasil yang menggembirakan. 
Langkah Strategis Menghadapi Situasi Ekonomi-Politik Indonesia (Edi Suandi Hamid)

Tabel 1 Perkembangan Indikator Tata Pamong Indonesia, 1996 dan 2010

\begin{tabular}{|c|c|c|c|c|c|c|c|c|c|c|c|c|}
\hline $\begin{array}{l}\text { World } \\
\text { Governance } \\
\text { Indicators }\end{array}$ & 1996 & 1998 & 2000 & 2002 & $\begin{array}{r}3 \\
2003 \\
\end{array}$ & 2004 & 2005 & $\begin{array}{r}72 \\
4 \\
2006 \\
\end{array}$ & 2007 & 2008 & 2009 & 2010 \\
\hline & -0.82 & .03 & -0.44 & -0.41 & -0.35 & -0.28 & -0.17 & -0.14 & -0.12 & -0.11 & -0.08 & -0.06 \\
\hline $\begin{array}{l}\text { Political Stability } \\
\& \text { Absence } \\
\text { of Violence/ } \\
\text { Terrorism } \\
\end{array}$ & 1.17 & -1.72 & -2.01 & -1.61 & -2.13 & -1.84 & -1.45 & -1.37 & -1.17 & -1.06 & -0.78 & -0.89 \\
\hline & -0.40 & -0.60 & -0.31 & -0.47 & -0.47 & -0.37 & -0.42 & -0.28 & -0.27 & -0.23 & -0.26 & -0.20 \\
\hline $\begin{array}{l}\text { Regulatory } \\
\text { Quality }\end{array}$ & 0.15 & -0.30 & -0.26 & -0.65 & -0.77 & -0.67 & $-0,55$ & -0.32 & -0.32 & -0.30 & -0.32 & -0.38 \\
\hline Rule of Law & -0.32 & -0.68 & -0.76 & -0.95 & -0.91 & -0.76 & -0.83 & -0.72 & -0.65 & -0.63 & -0.60 & -0.63 \\
\hline $\begin{array}{l}\text { Control of } \\
\text { Corruption }\end{array}$ & -0.56 & -1.09 & -0.88 & -1.14 & -0.98 & -0.90 & -0.86 & -0.78 & -0.57 & -0.58 & -0.81 & -0.73 \\
\hline
\end{tabular}

Sumber: Diolah dari lampiran Kaufmann, Kraay, dan Mastruzzi (2008) dikutip dari The

Worldwide Governance Indicators (WGI) project(2011).

Data pada tabel di atas menunjukkan adanya enam indikator tata pamong yang dinilai, yaitu voice and accountability, political stability and absence of violence/terorrism, government effectiveness, regulatory quality, rule of law dan control of curroption.Selama masa reformasi berlangsung hanya voice and accountability yang menunjukkan perubahan signifikan ke arah yang lebih baik. Indikator lainnya memang menunjukkan perubahan, tetapi relatif lambat, seperti political stability and absence of violence/terorrismyang mulai menunjukkan kinerja lebih baik pada tahun 2008, government effectiveness mulai dari 2006. Sedangkan indikator lainnya, sampai saat ini masih kalah jika dibandingkan dengan tahun 1996.

Indikator lainnya, yaitu Regulation quality, Rule of law, dan Control of corruption, justru terlihat semakin memburuk selama masa Reformasi. Kualitas perundangan yang buruk dapat dengan mudah dilihat dari sedikitnya undang-undang yang berhasil disahkan setiap masa tugas DPR dan rendahnya kualitas undang-undang yang dihasilkan karena seringnya. Mahkamah Konstitusi mengabulkan gugatan judicial review dan menganulir ayat atau pasal dalam sebuah undang-undang yang proses pengesahannya memakan banyak waktu dan biaya. Penegakan hukum yang masih lemah seperti saat ini juga menjadi indikasi kuat makin kurangnya kepercayaan masyarakat terhadap aparat, sehingga kekerasan berdimensi sosial, ekonomi, dan politik, bahkan agama kerap terjadi dan memakan banyak korban.

Kinerja pemerintahan yang belum optimal pada akhirnya akan menyebabkan gagalnya negara dalam menjaga dan mengelola sumber daya pembangunan. Korupsi yang makin masif adalah indikasi gagalnya negara memanfaatkan sumberdaya yang ada untuk pembangunan. Gambaran ini nampak jelas dalam kasus korupsi di Indonesia yang belum menunjukkan trend perbaikan meskipun berbagai kasus telah diungkap. Sebagaimana nampak pada tabel di bawah ini, korupsi di Indonesia termasuk dalam kategori yang paling buruk dari berbagai negara yang disurvei oleh Transparency International. 
Tabel 4. Corruption Perception Index Indonesia dan Sejumlah Negara, 1995-2011

\begin{tabular}{|c|c|c|c|c|c|c|c|c|c|}
\hline \multirow{2}{*}{ Negara } & \multicolumn{9}{|c|}{ CountryRankicorrupfion Rercepfon lindex } \\
\hline & 1995 & 1997 & 1999 & 2001 & 2003 & 2005 & 2007 & 2009 & 2010 \\
\hline Indonesia & 411 & $46^{2}$ & $96^{3}$ & $88^{4}$ & $122^{5}$ & $137^{6}$ & $143^{7}$ & $111^{8}$ & $100^{9}$ \\
\hline Malaysia & 30 & 32 & 32 & 36 & 37 & 39 & 43 & 56 & 60 \\
\hline Thailand & 41 & 39 & 68 & 61 & 70 & 59 & 84 & 84 & 80 \\
\hline Korsel & 34 & 34 & 50 & 42 & 50 & 40 & 43 & 39 & 43 \\
\hline
\end{tabular}

${ }^{1}=$ dari 41 negara, ${ }^{2}=$ dari 52 negara, ${ }^{3}=$ dari 99 negara, ${ }^{4}=$ dari 91 negara,

${ }^{5}=$ dari 133 negara, ${ }^{6}=$ dari 158 negara, ${ }^{7}=$ dari 179 negara ${ }^{8}=$ dari 180 negara,

$$
9=\text { dari } 182 \text { negara. }
$$

Sumber: Diolah dari Transparency International Corruption Perceptions Index (CPI) berbagai edisi (1995- 2011).

Beriringan dengan kedua indikator di atas, korupsi sebagai masalah kronis makin menggurita di berbagai aspek kehidupan. Korupsi tidak hanya menyebabkan distorsi kebijakan ekonomi akibat tidak terdistribusikannya uang rakyat untuk pembangunan. Korupsi dan pemberitaanya juga telah menguras banyak waktu pemerintah untuk berkonsentrasi pada upaya penyejahteraan rakyat. Kemendagri pada pertengahan 2011 lalu misalnya menyebutkan terdapat sekitar 156 kasus korupsi yang melibatkan bupati, walikota, dan gubernur, sehingga hampir setiap pekan Mendagri harus menerima surat permohonan penonaktifan pejabat bersangkutan.

Kondisi ini tentunya sangat mengganggu kualitas pembangunan di daerah. Lebih dari itu, korupsi saat ini telah menjadi headline harian, trending topic, dan kata kunci paling dicari, sehingga seluruh informasi publik saat ini sangat sarat dengan korupsi. Hal ini tidak saja menguras tenaga, pikiran, dan waktu pejabat publik maupun masyarakat, tetapi juga berisiko membentuk budaya korupsi pada generasi muda. Mudahnya memperoleh berita korupsi sangat mungkin justru akan membuat mereka nantinya lebih 'ahli' karena sejak semula telah merasa terbiasa dengan berita semacam itu.

Gambaran ini menunjukkan bahwa kapasitas pemerintah dalam menerapkan nilai-nilai kepemimpinan dalam berbagai aspek masih teramat lemah. Sehingga good governance tidak berjalan secara optimal. Akibatnya akuntabilitas publik sebagai bentuk pertanggungjawaban pengelolaan keuangan negara terkesan diabaikan dan menghilangkan peluang ekonomi dari keuangan negara yang hilang akibat korupsi.

Kapasitas kepemimpinan nasional pemerintah yang lemah dan menyebabkan masifnya korupsi ini juga terjadi dalam konteks partai politik sebagai salah satu instrumen politik di tanah air. Akuntabilitas dalam proses kampanye yang meliputi dana kampanye, sumbangan individu dan institusi yang pada dasarnya wajib menjadi informasi publik terbukti susah untuk disampaikan partai politik. Lebih jauh lagi, proses demokratisasi Indonesia saat ini yang dilakukan melalui pesta demokrasi, pemilu, juga mengalami tantangan yang cukup berat, yaitu dengan merabaknya politik uang (money politics) yang selama ini seolah telah menjadi bagian dari proses pemilihan umum (Pemilu) di Indonesia.

Mulai dari pemilihan kepala daerah secara langsung, pemilihan legislatif, hingga pemilihan presiden, yang beberapa waktu diadakan di Indonesia, tidak sedikit kasus money politics yang sempat dibongkar. Namun, dalam memprosesnya kasus-kasus ini, para pihak yang diberikan wewenang terlihat belum memiliki kekuatan yang cukup. Aturan hukum terindikasi menjadi salah satu faktor memperlemah kekuatan untuk memproses kasus-kasus money politics yang kerap terjadi dalam pesta rakyat Indonesia. 
Permasalahan tata pamong selama masa Reformasi ini menunjukkan bahwa proses demokratisasi yang terus berlangsung belum mampu menciptakan pemerintahan yang secara efektif mampu menjaga stabilitas dan keamanan, mengelola pemerintahan secara efektif; membuat perundangan yang berkualitas, menegakkan hukum, dan mencegah korupsi. Dengan kọndisi pemerintahan semacam ini, nampak wajar jika kemudian performa ekonomi tidak sepenuhnya berjalan maksimal, karena kualitas kebijakan dan implementasinya di lapangan memang susah untuk bisa diharapkan memberikan hasil-hasil yang maksimal bagi kepentingan rakyat banyak.

Kegagalan dalam mengelola tata pamong tersebut terlihat dengan jelas dari kinerja ekonomi, terutama di bidang kesejahteraan rakyat. Indonesia sebagai sebuah perekonomian yang mampu tumbuh lebih dari $6 \%$ di tengah krisis global, tidak mampu memanfaatkan pertumbuhan tersebut untuk meningkatkan kesejahteraan secara signifikan. Pertumbuhan diatas $6 \%$ yang sedemikian dibanggakan belum mampu mengurangi pengangguran maupun penduduk miskin secara signifikan.

Tabel berikut menunjukkan kinerja perekonomian terhadap indjkator ketenagakerjaan selama beberapa tahun terakhir. Pertumbuhan diatas $6 \%$ yang selama ini kita rasakan ternyata hanya mampu menyerap sekitar satu.juta penduduk untuk masuk ke dunia kerja. Hal ini menandakan, bahwa pertumbuhan yang terjadi masih belum berkualitas karena setiap satu persennya hanya mampu menyerap kurang dari dua ratus ribu penduduk yang menganggur. Dengan kondisi semacam ini wajar jika muncul pesimisme bahwa pertumbuhan ekonomi akan berdampak banyak bagi masyarakat karena faktanya memang pertumbuhan belum mampu' berbicara banyak.

Tabel 2 Indikator Ketenagakerjaan Indonesia Agustus 2004- Agustus 2011 (juta orang)

\begin{tabular}{|c|c|c|c|c|c|c|c|c|c|c|c|c|c|c|c|}
\hline • & $\begin{array}{c}\text { Agust } \\
2004\end{array}$ & $\begin{array}{l}\text { Feb } \\
2005\end{array}$ & $\begin{array}{l}\text { Nov } \\
2005\end{array}$ & $\begin{array}{l}\text { Feb } \\
2006\end{array}$ & $\begin{array}{c}\text { Agust } \\
2006\end{array}$ & $\begin{array}{l}\text { Feb } \\
2007\end{array}$ & $\begin{array}{c}\text { Agust } \\
2007\end{array}$ & $\begin{array}{l}\text { Fëb } \\
2008\end{array}$ & $\begin{array}{c}\text { Agust } \\
2008\end{array}$ & $\begin{array}{l}\text { Feb } \\
2009\end{array}$ & $\begin{array}{c}\text { Agust } \\
2009\end{array}$ & $\begin{array}{c}\text { Feb } \\
2010\end{array}$ & $\begin{array}{c}\text { Agust } \\
2010\end{array}$ & $\begin{array}{l}\text { Feb } \\
2011\end{array}$ & $\begin{array}{c}\text { Agust } \\
2011\end{array}$ \\
\hline $\begin{array}{l}\text { Angkatan } \\
\text { Kerja }\end{array}$ & 104,0 & 105,8 & 105,9 & 106,3 & 106,4 & 108,1 & 109,9 & 111,48 & 111,95 & 113,74 & 113,83 & 116,00 & 116,53 & 119,40 & 117,37 \\
\hline Bekerja & 93,7 & 94,9 & 94,0 & 95,2 & 95,5 & 97,6 & 99,9 & 102,05 & 102,55 & 104,49 & 104,87 & 107,41 & 108,21 & 111,28 & 109,67 \\
\hline $\begin{array}{l}\text { Pengang } \\
\text { gur }\end{array}$ & $.10,3$ & 10,9 & 11.9 & 11,1 & 10,9 & 10,5 & 10,0 & 9,43 & 9,39 & 9,26 & 8,96 & 8,59 & 8,32 & 8,12 & 7,70 \\
\hline
\end{tabular}

Sumber: Badan Pusat Statistik berbagai edisi.

Permasalahan pertumbuhan yang kurang berkualitas ini, juga terasa dalam kemampuan mengurangi penduduk miskin. Jumlah penduduk yang berhasil dientaskan selama beberapa tahun terakhir juga masih berada pada kisaran satu jutaan. Itupun biasanya diiringi dengan sejumlah kritik baik pada metode yang diacu pemerintah maupun pada realitas yang ada di lapangan. Tabel berikut menyajikan data jumlah penduduk miskin dan presentasenya dalam beberapa tahun terakhir. Data yang ada menunjukkan, pertumbuhan di atas $6 \%$ selama. beberapa tahun terakhir baru mengurangi penduduk miskin dalam kisaran satu juta penduduk. Jumlah penduduk miskin yang mencapai hampir 30 juta jiwa atau $12 \%$ lebih dari jumlah penduduk tentu harus menjadi perhatian serius.

Tabel 3 Jumlah dan Presentase Penduduk Miskin di Indonesia 2004-2011

\begin{tabular}{|c|c|c|}
\hline Tahun & $\begin{array}{c}\text { Jumlah Penduduk } \\
\text { Miskin (juta) }\end{array}$ & $\begin{array}{c}\text { Presentase } \\
\text { Penduduk Miskin }\end{array}$ \\
\hline Maret 2004 & 36,10 & 16,66 \\
\hline Maret 2005 & 35,10 & 15,97 \\
\hline Maret 2006 & 39,30 & 17,75 \\
\hline
\end{tabular}




\begin{tabular}{|c|c|c|}
\hline Maret 2007 & 37,17 & 16,58 \\
\hline Maret 2008 & 34,96 & 15,42 \\
\hline Maret 2009 & 32,53 & 14,15 \\
\hline Maret 2010 & 31,02 & 13,33 \\
\hline Maret 2011 & 30,02 & 12,49 \\
\hline September 2011 & 29,89 & 12,36 \\
\hline
\end{tabular}

Sumber: Badan Pusat Statistik (2012:4)

Kehidupan rakyat yang secara umum masih kekurangan dapat kita simak hampir setiap hari melalui media, dengan beragam bentuknya, mulai dari masalah kesehatan, pendidikan, dan sebagainya yang menunjukkan masih beratnya hidup sebagai warga miskin di Indonesia. Jika ditambah dengan beragam gejolak di masyarakat yang ramai terjadi belakangan ini, kemiskinan sebagai fenomena kehidupan rakyat Indonesia, makin menunjukkan sifat aslinya. Karena kemiskinan, masyarakat makin mudah tersulut emosi kolektifnya sehingga mudah diprovokasi untuk kepentingan politik dan ekonomi tertentu. Kondisi ini masih ditambah dengan rentannya rakyat kecil terhadap kebijakan ekonomi pemerintah (rencana kenaikan harga BBM, dan sebagainya) maupun dampak lanjutan krisis keuangan global.

Pembangunan ekonomi selama ini juga masih didominasi oleh konsumsi (consumptiondriven), terutama oleh masyarakat menengah ke atas. Porsi konsumsi ini dalam Pendapatan Domestik Bruto beberapa tahun terakhir mencapai lebih dari 50\% yang menandakan masyarakat kita yang konsumtif. Konsumsi yang besar ini sangat mungkin didominasi masyarakat kelompok berpenghasilan $20 \%$ teratas yang share konsumsinya semakin meningkat. Sedangkan di sisi lain, masyarakat dengan pendapatan rendah, semakin kecil porsi konsumsinya. Kondisi ini dengan demikian menyiratkan bahwa angka-angka pertumbuhan yang selama ini kita lihat dan banggakan sangat bias karena tidak dapat menjadi cerminan sesungguhnya pola kehidupan masyarakat, terutama mereka yang berada dalam garis kemiskinan. Sehingga tidak mengherankan jika di satu sisi pertumbuhan ekonomi diangap prestasi oleh pemerintah namun pada saat yang sama, masyarakat miskin justru makin menuntut hak-hak asasi ekonominya dipenuhi, sebagaimana kita lihat dalam demo buruh yang belakangan ini marak di berbagai kota di Indonesia.

Tabel 4 Indeks Gini

\begin{tabular}{|l|c|c|c|c|c|c|}
\hline Kelompok penduduk & $\mathbf{2 0 0 2}$ & $\mathbf{2 0 0 3}$ & $\mathbf{2 0 0 4}$ & $\mathbf{2 0 0 5}$ & $\mathbf{2 0 0 6}$ & $\mathbf{2 0 0 7}$ \\
\hline $\mathbf{4 0 \%}$ terendah & 20,92 & 20,57 & 20,80 & 18,81 & 19,75 & 19,10 \\
\hline $\mathbf{4 0 \%}$ menengah & $\mathbf{3 8 , 8 9}$ & 37,10 & 37,13 & 36,40 & 38,10 & 36,11 \\
\hline $\mathbf{2 0 \%}$ teratas & 42,19 & 42,33 & 42,07 & 44,78 & 42,15 & 44,79 \\
\hline Indeks Gini & 0,33 & 0,32 & 0,32 & 0,36 & 0,33 & 0,37 \\
\hline
\end{tabular}

Sumber: BPS, dikutip dari Bank Indonesia (2008) Tabel 2.16.

Rendahnya kemampuan masyarakat miskin dalam menikmati hasil pembangunan antara lain dapat dijelaskan dari konsentrasi penyerapan tenaga kerja pada yang demikian besar pada sektor pertanian. Padahal di sektor ini upah yang diperoleh jauh lebih rendah dibandingkan dengan sektor lainnya (Sitanggang dan Nachrowi, 2004). Hal ini dimungkinkan terjadi mengingat rendahnya daya serap dan aplikasi teknologi sebagai kerangka pendukung sektor pertanian seperti di negara-negara maju. Padahal dari sektor-sektor industri lainnya pendapatan (upah) yang diterima tenaga kerja masih jauh dari standar ekonomi, atau masih terbatas pada pemenuhan kebutuhan rata-rata saja. 
Langkah Strategis Menghadapi Situasi Ekonomi-Politik Indonesia (Edi Suandi Hamid)

Tabel 18 Penduduk Berumur 15 Tahun Ke Atas Menurut Lapangan Kerja Utama, 2008-2011 (juta orang)

\begin{tabular}{|c|c|c|c|c|c|c|c|c|}
\hline \multirow{2}{*}{ Jeniskeglatan Utama } & \multicolumn{2}{|c|}{2008} & \multicolumn{2}{|c|}{2009} & \multicolumn{2}{|c|}{2010} & \multicolumn{2}{|c|}{2011} \\
\hline & Fébruan & Agustus & Fébraad. & Agustus & Fébruan & Agustus & Eëbruad & Agustus \\
\hline Pertanian & 42.69 & 41.33 & 43.03 & 41.61 & 42.83 & 41,49 & 42,48 & 39,33 \\
\hline Industri & 12.44 & 12.55 & 12.62 & 12.84 & 13.05 & 13,82 & 13,70 & 14,54 \\
\hline Konstruksi & 4.73 & 5.44 & 4.61 & 5.49 & 4.84 & 5,59 & 5,59 & 6,34 \\
\hline Perdagangan & 20.68 & 21.22 & 21.84 & 21.95 & 22.21 & 22,49 & 23,24 & 23,40 \\
\hline $\begin{array}{l}\text { Transportasi, } \\
\text { Pergudangan dan } \\
\text { Komunikasi }\end{array}$ & 6.01 & 6.18 & 5.95 & 6.12 & 5.82 & 5,62 & 5,58 & 5,08 \\
\hline Keuangan & 1.44 & 1.46 & 1.48 & 1.49 & $1 . \overline{64}$ & 1,74 & 2,06 & 2,63 \\
\hline Jasa Kemasyarakatan & 12.78 & 13.10 & 13.61 & 14.00 & 15.62 & 15,96 & $\overline{17,02}$ & 16,65 \\
\hline Lainnya ") & 1.27 & 1.27 & 1.35 & 1.39 & 1.40 & 1,50 & 1,61 & 1,70 \\
\hline Total & 102.05 & 102.55 & 104.49 & 104.87 & 107.41 & 108,21 & 111,28 & 109,67 \\
\hline
\end{tabular}

*) Lapangan pekerjaan utama/sektor lainnya terdiri dari : Sektor Pertambangan, Listrik, Gas . dañAir

Sumber: Badan Pusat Statistik berbagai edisi, diolah.

Data BPS menunjukkan rata-rata pekerja di sektor pertanian di Indonesia mencapai lebih dari 42 juta jiwa dalam tiga tahun terakhir. Mereka yang bekerja dalam sektor ini merupakan kelompok penduduk yang sangat rentan terhadap perubahan ekonomi. Mereka biasanya merupakan petani penggarap dan jikapun memiliki lahan sendiri jumlahnya sangat terbatas, Mereka juga rentang dengan kenaikan harga faktor produksi berupa benih dan pupuk, serta resiko turunnya harga saat panen maupun tingginya harga saat musim paceklik.

Gabungan antara keterbatasan belanja pendidikan dan dominasi pekerjaan pada sektor pertanian ini antara lain yang kemudian menjadikan daya saing bangsa relatif belum maksimal dicapai. Pendidikan dengan seluruh institusi dan elemen di dalamnya kemudian dianggap ikut atau bahkan paling bertanggung jawab dalam mengatasi masalah ini. Anggapan bahkan tudingan semacam ini memang wajar terdengar karena diakui atau tidak, tidak semua produk pendidikan kita saat ini mampu berdaya saing dalam kehidupan ekonomi maupun sektor lainnya. Indikasinya dapat kita lihat dari masih besarnya tingkat pengangguran yang berasal dari alumni pendidikan, termasuk pendidikan tinggi.

Tabel 19 Tingkat Pengangguran Terbuka (TPT) Menurut Pendidikan Tertinggi yang

Ditamatkan, 2008-2011. (persen)

\begin{tabular}{|l|r|r|r|r|r|r|r|r|}
\hline $\begin{array}{l}\text { Pendidikan Tertinggi yang } \\
\text { Ditamatkan }\end{array}$ & \multicolumn{2}{|c|}{2008} & \multicolumn{2}{c|}{2009} & \multicolumn{2}{c|}{2010} & \multicolumn{2}{c|}{2011} \\
\cline { 2 - 9 } & Februari & Agustus & Februari & Agustus & Februari & Agustus & Februari & Agustus \\
\hline SD ke Bawah & 4.70 & 4.57 & 4.51 & 3.78 & 3.71 & 3,81 & 3,37 & 3,56 \\
\hline Sekolah Menengah Pertama & 10.05 & 9.39 & 9.38 & 8.37 & 7.55 & 7,45 & 7,83 & 8,37 \\
\hline Sekolah Menengah Atas & 13.69 & 14.31 & 12.36 & 14.50 & 11.90 & 11,90 & 12,17 & 10,66 \\
\hline $\begin{array}{l}\text { Sekolah Menengah } \\
\text { Kejuruan }\end{array}$ & 14.80 & 17.26 & 15.69 & 14.59 & 13.81 & 11,87 & 10,00 & 10,43 \\
\hline Diploma I/IIIII & 16.35 & 11.21 & 15.38 & 13.66 & 15.71 & 12,78 & 11,59 & 7,16 \\
\hline Universitas & 14.25 & 12.59 & 12.94 & 13.08 & 14.24 & 11,92 & 9,95 & 8,02 \\
\hline T o t a I & 8.46 & 8.39 & 8.14 & 7.87 & 7.41 & 7,14 & 6,80 & 6,56 \\
\hline
\end{tabular}

Sumber: Badan Pusat Statistik berbagai edisi, diolah. 
Data BPS di atas menunjukkan masih tingginya penduduk berpendidjkan yang menjadi pengangguran atau berada di luar dunia produktif. Bahkan lulusan SMA, SMK dan PT masingmasing menyumbang lebih dari $10 \%$ selama tiga tahun terakhir. Dengan segala permasalahan di atas, mulai dari politik, ekonomi, kepemimpinan, hingga pendidikan wajar kiranya jika isu etika dan integritas bangsa kembali muncul.Etika politik yang makin luntur menjadi salah satu alasan utama mengapa bangsa ini masuk dalam masalah yang begitu akut di berbagai bidang. Politisi kita semakin hari semakin menunjukkan kapasitas sebagai politisi yang menghalalkan segala cara untuk mencapai tujuan pribadi dan kelompok. Indikasinya selain korupsi berjamaah yang diulas sebelummya, juga pada upaya terorganisir untuk melokalisasi setiap kasus korupsi yang dimajukan ke meja hijau. Sehingga yang terjadi kemudian adalah kasus korupsi dengan pemberitaan yang menghebohkan, pada saat pelarian, penangkapan, ataupun pengakuan terdakwa, namun berakhir anti klimaks di pengadilan.

Kondisi ini menunjukkan masih jaụhnya kapasitas politisi kita untuk disebut negarawan apalagi disetarakan dengan para pendiri bangsa yang dengan lugas memberikan contoh bagaimana seharusnya seorang politisi berkorban untuk bangsa dan negaranya. Perilaku politik politisi kita pun juga tidak jauh berbeda dengan perilaku hariannya yang menjadikan mereka jauh dari teladan bagi bangsa dan terutama anak didik. Pada saat yang sama, politisi yang mendapat amanah dj pemerintahan juga belum sepenuhnya mampu melaksanakan tugasnya dengan baik, sehingga kebijakan yang diambil masih jauh dari orientasi kesejahteraan rakyat, bahkan tidak jarang hanya menguntungkan segelintir pihak.

Kebijakan subsidi BBM yang akan digulirkan melalui RAPBN-P yang telah diajukan ke DPR misalnya menjadi gambaran betapa kurang maksimalnya pemerintah memanfaatkan amanah kekuasaan. Kebijakan ini terus menerus menuai kritik baik dari sisi akademik, maupun praktis, karena tiadanya transparansi pengambilan kebijakan. Selain itu, paradigma berfikir yang terlalu berorientasi dan mengacu pada paradigma ekonomi kapitalisme ala barat, menjadikan masalah ini makin jauh dari substansi kesejahteraan sebagai amanah konstitusi. Kebijakan-kebijakan semacam inilah yang kemudian membuat rakyat menjadi mudah marah karena sudah tidak lagi memiliki respect terhadap pemerintah.

Akibat lanjutannya tentu saja dapat mengancam integritas bangsa yang memang mudah dipanasi jjka kondisi ekonomi kurang menguntungkan. Kita harus ingat bahwa perubahan besar di negara kita, sejak masa Orde Lama, Orde Baru, dan Era Reformasi ini senantiasa dimulai dari ketidak percayaan rakyat terhadap pemerintah karena kegagalan dalam memberikan jaminan kesejahteraan. Kita tidak boleh lupa akan hal ini, karena kealpaan akan berdampak pada perubahan besar yang senantiasa diiringi dengan huru-hara disertai dengan biaya ekonomi, sosial, dan politik yang besar.

\section{Globalisasi dan Pengaruhnya terhadap Indonesia}

Selain kondisj internal yang kita alami di atas, masalah juga muncul dari makin terintegrasinya perekonomian kita dengan dunia luar melalui globalisasi di hampir segala bidang. Kata "globalisasj" sudah sangat akrab di telinga publik, dan isu itu terus menerus menjadi perhatian masyarakat dunia saat ini. Namun demikian, penggunaan istilah ini sudah demikian meluas, tidak semuanya mengandung pengertian yang sama. Sebagaimana dikemukakan Merret (2005: 23), pengajar matakuliah Global Management Issues di Univesity of Melbourne bahwa "there is little consensus about what 'globalisation' is and whether its outcomes are for better or worse". Globalisasi ekonomi masih mengandung banyak pertanyaan dan perdebatan, khususnya tentang untung-ruginya bagi masyarakat dunia secara keseluruhan.

Dalam pengertian umum, Davies dan Nyland (2004: 5-6) menemukan lima pengertian globalisasi tersebut, yaitu (1) internasionalisasi; (2) liberalisasi; (3) universalisasi 
(universalization); (4) Westernisasi (westernization) atau modenisasi; dan (5) suprateritorialitas (supraterritoriality), yang mengandung makna bahwa "ruang sosial tidak lagi dipetakan atas dasar tempat, jarak, dan batas-batas wilayah". Secara lebih sempit yang mengaitkannya degan ekonomi, Pieterse (2001:1) mendefiniskan globalisasi sebagai proses percepatan untuk menyatukan (intermeshing) dunia dalam bidang ekonomi. Secara lebih rinci dikemukakannya:

".... the accelerated worldwide intermeshing of economies, and cros's border traffic and communication becoming ever denser. Technological change is speeding up.:Risks and opportunities are globalizing.... Glóbalization means global effect and global awareness, and therefore increasingly it also means global engagement, "(loc: cit).

Walaupun tidak eksplisit menyebutkan globalisasi ekonomi, Stiglitz dalam bukunya yang sangat terkenal, "Globalization and Its Discontents" (2002: ix) mengartikan globalisasi sebagai "penghapusan berbagai hambatan perdagangan untuk mewujudkan perdagangan bebas dan memperkuat integrasi ekonomi antarnegara". Secara lebih luas dikemukakannya "globalisasi sebagai penyatuan yang semakin dekat antara negara-negara dan masyarakatmasyarakat di dunia yang disebabkan oleh penurunan yang besar dari biaya transportasi dan komunikasi, dan dihapuskannya berbagai penghalang artifisial bagi arus barang, jasa, modal, pengetahuan, dan (dalam skala yang lebih kecil) lintas batas manusia (ibid.: 9). Sedang Anne Krueger, seorang petinggi IMF, mendefinisikannya sebagai "a phenomenon by which economic agents in any given part of the world are much more affected by events elsewhere in the world than before" (Wolf, 2004: 14). Dalam pengertian yang hampir sama Djiwandono (2004: 1) menyatakan bahwa globalisasi adalah hilangnya batas-batas atau sekat-sekat antarnegara di mana dunia menjadi tanpa batas atau borderless. Jadi, dalam perspektif ekonomi, globalisasj merupakan suatu pengintegrasian ekonomi secara global.

Dengan demikian, jikka globalisasi ekonómi mewujud - dalam arti luas - berarti tidak ada lagi batas-batas negara dalam transaksi 'ekonomi. Komoditi menjadi bebas tanpa hambatan untuk berpindah dari satu negara ke nè gara lainnya. Tidak âdà lagi hambatan-hambatan bisnis atau perdagangan internasional, baik berupa tariff barriers maựpun non-tarif barriers (Hamid, 2004). Memang demikian banyak rumusan mengenai globalisasi ekonomi. Namun apapun pengertiannya substansi yang selalu melekat hampir sama, yakni upaya untuk menyatukan atau mengintegrasikan perekonomian global.

Dari perspektif historis, upaya menyatukan ekonomi global tersebut sudah berlangsung sejak lama. Menurut Elwood (2001:12-13) globalisasi ekonomi sebagai suatu kata atau istilah memang merupakan terminologi yang baru, namun sebagai aktivitas mengglobalnya ekonomi itu sudah berlangsung sangat lama, yakni sejak masa kolonialisme Eropa lima abad yang lalu. Globalisasi ekonomi waktu itu terjadi untuk mendapatkan kekayaan di belahan dunia yang sebelumnya tidak terjangkau. Cristobal Colon, yang kemudian dikenal dengan nama Christopher Columbus, dengan dukungan dana dari, Raja dan Ratu Spanyol berlayar mengarungi lautan untuk menuju wilayah Asia yang diberitakan berlimpah dengan kekayaan alam dan emasnya. Upaya mencari wilayah baru untuk memperoleh kekayaan bagi negara yang relatif kaya semacam ini terus berlanjut. Dalam catatan sejarah yang terkait dengan globalisasi lainnya, dapat dikemukakan upaya yang dilakukan jurubicara terkenal Kerajaan Inggris tahun 1890-an, Cecil Rhodes, yang menyatakan perlunya negara mendapatkan tanah yang baru, karena lahan (jajahan) yang baru tersebut bisa menguntungkan negerinya:

"... from which we can easily obtain raw materials and at the "same time exploit the cheap slave labor that is available from natives of the colonies. The colonies (will) "also provide a dumping ground for the suprius goods produced in our factories" (Khior dalam Elwood, 2001: 13). 
Pandangan-pandangan démikian merupakan pandangan kaum merkantlis pada abad ke-17 dan ke-18, yang menjadikan globalisasi ekonomi guna memperoleh surplus pèrdagangan dalam rangka memperkuat negarányá. Alexander Hamilton, tokoh merkantilis dari Amerika Serikat pada tahun 1791 berkaitan dengan kebijakan proteksi AS di bidang industri menulis: "Not only the wealth but the independence and security of a country appears to be materially connected to the prosperity of manufactures" (Gilpin, 2002: 92).

Jadi upaya globalisasi era kolonial diarahkan untuk memenuhi kebutuhan negara yang sudah lebih dulu maju dengan mengeksploitasi negara atau daerah yang masih terbelakang. Globalisasi ekonomi yang sudah berakar sejak berabad-abad tersebut terus berevolusi. Titik yang signifikan terjadi tahun 1947 saat mulai berlakunya dan dilembagakannya Perjanjian Umum tentang Tariff dan Perdagangan atau GATT (General Agreement on Tariffs and Trade). Komitmen yang mengarah pada globalisasi perdagangan dunia yang dimotori oleh Amerika Serikat tersebut pertama kali hanya diikuti oleh 23 negara. Evolusi globalisasi ekonomi ini kemudian berkembang sangat cepat sejak akhir 1980-an'. Melalui perundingan panjang yang dilakukan GATT selama 8 tahun, yang dikenal dengan Putaran Uruguay pada tahun 1995 berhasil memutuskan membentuk World Trade Organization (WTO). Keanggotaan WTO ini terus berkembang dengan bidang cakupan yang lebih luas, yakni menyangkut liberalisasi lalulintas barang dan jasa (GATS).

Secara garis bes'ar, evolúsi atau kecenderungan globalisasi inj dapat dikategorisasikan menjadi tiga tahap (Djiwandono, 2004: 3), yaitu: (a) gelombang pertama antarà tahun 18701914. Periode ini ditandai perkembangan dalam peralatan transportasi dan penurunan rintangan perdagangan sehingga meningkatkan perdagangan internasional dan investasi oleh negara-negara Amerika Utara dan Eropa ke berbagai kawasan; (b) gelombang kedua antara tahun 1950-1980, yang ditandai oleh integrasi negara-negara kaya, seperti Amerika Serikat, Eropa, dan Jepang. Laju pertumbuhan negara berkembang juga meningkat, namun umumnya jurang perbedaan antara negara maju dengan negara berkembang semakin besar; (c) gelombang globalisasi mutakhir mulai tahun 1980-sekarang, yang ditandai oleh kemajuan teknologi transportasi, komunikasi, perkembangan sejumlah negara-negara berkembang yang membuka diri terhadap perdagangan luar negeri dan investasi asing (Washington Concensus). Dapat dikatakan sejak akhir 1980-an globalisasi yang sebelumnya berjalan lamban, berubah dari proses evolusi menjadi revolusi .

Dari perspektif teoritis, globalisasi ekonomi menjanjikan manfaat yang sangat menggiurkan: meningkatnya kesejahteraan masyarakat dunia. Dengan penghapusan berbagai rintangan dalam hubungan ekonomi internasional akan mendorong peningkatan efisiensi dan produksi barang dan jasa. Spesialisasi ekonomi terjadi. Perdagan'gan dan investasi meningkat, teknologi produksi berkembang, yang kesemuanya mengarahkan pada peningkatan output dunia, yang berarti kesejahteraan dunia secara total juga meningkat (Lihat misalnya El-Agraa, 1988: 10). Oleh karena itu, berbagai'hambatan perdagangan, baik itu yang berupa'tarif yang tinggi maupun yang bukan tarif harus diminimalkan, bahkan dihilangkan. Melalui WTO dan berbagai lembaga-lembaga internasional hal itu selalu menjadi kewajiban untuk dilaksanakan. Kebebasan ekonomi dunia dianggap sebagai suatu the best solution theory untuk meningkatkan output dunia. Dalam terminologi ekonomi, kebebasan ekonomi tersebut akan mewujudkan apa yang disebut sebagai Optimalitas Pareto (Pareto Optimality).

"Provokasi" yang didukung dengan konsep teori itu sangat gencar pada akhir 1980-an dan awal 1990-an. Oleh karena itu, tidak mengherankan kalau pada masa itu arus pemikiran tentang globalisasi ekonomi mewarnai hampir seluruh dunia. Terminologi yang berkaitan dengan globalisasi ini, seperti negara tanpa batas, liberalisasi ekonomi, perdagangan bebas, integrasi ekonomi global dan semacamnya menjadi semacam dogma yang diyakini akan membawa 
dunia pada kemajuan ekonomi, menghapuskan kemiskinan, serta memperkecil kesenjangan antarnegara. Upaya ke arah globalisasi ini sangat didukung negara-negara adikuasa ekonomi, yang memang pola perdagangannya sudah terbiasa dengan liberalisasi ekonomi. Globalisasi ekonomi dalam skala terbatas (atau disebut regionaliasi ekonomi) yang sering dianggap sebagai kisah sukses adalah integrasi ekonomi negara-negara Eropa Barat yang kini tergabung dalam Uni Eropa. Öleh karena itu, banyak negara yang "berlatih" untuk mempersiapkan diri ke arah globalisasi ekonomi melaluj intergasi ekonomi regional. Dalam kawasan Asia Pasifik di bentuk APEC (Asia Pacific Economic Cooperation) yang dimotori negara-negara seperti Australia, Amerika, dan Kanada. Dalam skala yang lebih kecil juga dibentuk North American Free Trade Area (NAFTA), ASEAN Free Trade Asrea (AFTA), dan sebagainya.

Berbagai perangkat organisasi ekonomi dunia itu diharapkan akan membantu percepatan pewujudan globalisasi untuk mengangkat kemakmurạn dunia. Pàra pendukung globalisasi ekonomi sangat yakin bahwa globalisasi menjanjikan terjadinya peningkatan kemakmuran dunia dan kerja sama internasional. Oleh karena itu mereka menyatakan tidak diperbolehkan. adanya rintangan yang dapat menghambat lalulintas barang, jasa, dan kapital (Gilpin, 2002: 293). Padahal, pemikiran untuk meliberalisasikan perdagangan dunia tersebut mempunyai prasyarat bahwa pelaku-pelaku yang akan mengintegrasikan ekonominya harus mempunyai kekuatan seimbang. Prakondisi inilah yang tidak terpenuhi, kekuatan ekonomi antarnegara masih sangat timpang, sehingga praktik globalisasi ekonomi belum bisa dilakukan. Kalaupun ingin dilaksanakan hal ini terbatas pada negara-negara yang relatif seimbang, yang bjasanya terbatas pada kawasan tertentu, yang dalam konsep teori disebut sebagai regional economic integration. Integrasi ekonomi regional seperti pembentukan perserikatan pabean (customs union) dianggap sebagai the theory of the second best karena prakondisi untuk mewujudkan the first bes't policy tidak bisa terpenuhi (lihal misalnya Chacholiades, 1988: 544-545).

Globalisasi yang terus berlangsungterbukti lebih banyak menguntungkan negara maju yang lebih siap bersaing. Negara maju yang telah lama memiliki dan mengimplementasikan aneka peraturan kompetitif mampu dengan mudah menyesuaikan diri terhadap tantangan globalisasi dan bahkan mendikte negara berkembang sebagai mitra dagangnya. Lebih dari itu, globalisasi yang saat ini ditopang sistem kapitalisme dengan konsentrasi kekuatan ekonomi pada perusahaan multinasional juga terbukti sangat rapuh. Buktinya adalah makin pendeknya siklus resesi ekonomi yang berdampak pada krisis di berbagai bidang, keuangan, utang, mata uang, dan lainnya. Dalam kondisi yang makin integratif, maka satu krisis yang terjadi. akan menyebar dengan cepat dan berdampak contagion ke seluruh dunia, termasuk negara berkembang yang sebenarnya tidak begitu menikmati hasil globalisasi.

Masalahnya kemudian, krisis yang diawali segelintir pihak yang rakus dalam berburu rente ekonomi ini kemudian menyerat banyak pihak lainnya. Dalam konteks ekonomi nasional misalnya, setiap terjadi krisis maka membawa dampak setidaknya pada pelaku ekonomi, pembuat kebijakan, dan rakyat secara umum. Bagi pelaku ekonomi, baik pemilik usaha kecil, menengah, maupun besar, krisis merupakan ukuran bagi kesehatan bisnis yang dikelola sekaligus jaminan akan kebersinambungan usaha di masa mendatang. Krisis dalam kacamata pelaku eknonomi merupakan tolak ukur rapuh ațau kuatnya basis usaha, hubungan ekonomi, dan signifikansi bisnis yang dipilih selama ini. Dengan demikian, dalam kacamata pelaku ekonomi, krisis secara umum tidak selalu berkonotasi negatif. Artinya bahwa selama bisnis yang dikelola menggunakan pendekatan yang tepat, maka krisis tidak akan merusak bisnis, bahkan berpeluang memperkuatnya. Sebaliknya jika krisis merusak bisnis, maka terdapat indikasi adanya permasalah internal dalam bisnis itu sendiri.

Bagi pembuat kebijakan, krisis merupakan ukuran baik buruknya sistem ekonomi yang selama ini diadopsi, kuat tidaknya struktur perekonomian yang selama ini dibangun, efektif 
tidaknya kebijakan yang selama ini diterapkan, dan sesuai tidaknya program yang selama ini dijalankan dengan dunia bisnis yang ada dalam sebuah negara. Jika krisis datang dan merusak tatanan ekonomi secara umum, maka itu merupakan gambaran bahwa pembuat kebijakan gagal mengarahkan ekonomi pada track yang benar. Adakalanya kegagalan menghadapi krisis berimbas pada kesadaran untuk melakukan perubahan paradigma dalam melihat perekonomian. Namun adakalanya krisis hanya dianggap sebagai hal biasa yang akan selalu ada dalam perekonomian, sehingga cukup dilakukan kebijakan peredam krisis, tanpa adanya perubahan signifikan.

Adapun bagi rakyat, secara keseluruhan krisis merupakan penyakit yang amat merugikan. Bagi rakyat kebanyakan penyebab dan pemicu krisis pada dasarnya jauh dari jangkauan mereka, namun dampaknya secara langsung dan tanpa dapat dihalangi akan menimpa mereka. Biaya yang mereka tanggung pun tidak kecil, mulai dari inflasi, yang mengurangi atau menghabiskan sama sekali daya beli mereka, melalui perlambatan ekonomi, yang menghambat potensi ekonomi, maupun melalui beban pajak yang akan diterima terkait kebijakan pemerintah untuk membiayai dampak krisis.

\section{Catatan atas Kelambatan Hasil Demokrasi dan Reformasi}

, Lingkungan strategis dan dampak globalisasi di atas menunjukkan bahwa sebagai bangsa praktek demokrasi yang kita terapkan selama masa reformasi masih menyimpan sejumlah masalah. Demokrasi kita yang dipuji banyak pihak karena dilakukan di negara dengan mayoritas penduduk muslim ternyata belum memberi hasil maksimal, terutama di bidang ekonomi. Mengapa proses demokratisasi yang tengah berlangsung terus-menerus gagal memberikan hasil terbaik bagi masyarakat? Hubungan antara demokrasi dan pembangunan ekonomi telah menjadi objek studi yang banyak dibicarakan. Studi yang dilakukan Przeworksi dan Limongi misalnya menyimpulkan bahwa proyek demokatisasi akan gagal dilaksanakan bila pembangunan ekonomi (diukur dengan pendapatan per kapita) suatu negara ada pada level rendah (Juoro, 2004). Dengan asumsi ini negara yang pendapatan per kapitanya di bawah 1.500 dollar AS sangat mungkin eksperimen demokrasinya hanya akan bertahan selama depalan tahun untuk kemudian mengalami kegagalan. Hal senada juga diungkapkan Seymor Martin Lipset yang hasil studinya memberikan postulat bahwa pertumbuhan ekonomi merupakan prasyarat terbukanya peluang demokratisasi di masa mendatang (Collier, 1979). Tanpa ada pertumbuhan ekonomi, sulit bagi terciptanya pemerintahan dan masyarakat demokatis (Yustika, 2004).

Namun demikian, studi lain memberikan kesimpulan yang sedikit banyak bertolak belakang dengan tesis Lipset dan Przeworsko dan Limongi. Tacares dan Wacziarg misalnya mengemukakan bahwa demokrasi bisa mendukung pertumbuhan ekonomi mellaui peningkatan akses pada pendidikan, kecilnya ketimpangan pendapatan, dan rendahnya konsumsi pemerintah. Sehingga dengan demikian terdapat efek dari demokrasi terhadap pertumbuhan ekonomi meskipun bersifat secara tidak langsung. Lebih jauh Barro (1996) menjelaskan, peningkatan hak-hak politik pada tahap awal proses demokratisasi cenderung meningkatkan investasi dan pertumbuhan ekonomi, meski di negara-negara yang sudah mencapai tingkat demokrasi tertentu peningkatan demokrasi akan menurunkan investasi dan pertumbuhan ekohomi karena ada tekahan untuk melakukan redistribusi pendapatan.

Secara lebih spesifik Barro menunjukkan bahwa beberapa indikator pembangunan seperti posisi awal pendapatan per kapita, pendidikan tingkat menengah dan perguruan tinggi, angka harapan hidup, fertilitas, konsumsi pemerintah, indeks aturan hukum, dan demokrasi berpengaruh signifikan terhadap pertumbuhan ekonomi. Khusus mengenai aturan hukum, parameter yang digunakan adalah sampai seberapa jauh kualitas birokrasi, kecenderungan korupsi, kebijakan pemerintah untuk membatalkan kontrak, resiko pemerintah 
menasionalisasikan kekayaan swasta (asing atau dalam negeri) dan pemeliharaan aturan hukum, digerakkan untuk mengelola kehidupan bernegara (Yustika, 2004).

Jika tesis Barro ini digunakan dalam konteks demokrastiasi di Indonesia, dapat kita simpulkan beberapa alasan mengapa proses demokratisasi yang berjalan belum sepenuhnya memberikan hasil yang siginifikan bagi pembangunan ekonomi nasional. Pertama proses demokratisasi yang tengah berlangsung di negara kita saat ini bisa jadi baru dalam tahap seremoni demokrasi. Dalam artian bahwa proses demokratisasi baru mewujud dalam bentuk paling awal berupa sebuah proses pemilihan yang melibatkan seluruh rakyat dan diikuti dengan terbentuknya pemerintahan yang demokratis karena dipilih langsung oleh rakyat.

Sedangkan tahapan lanjutan dari proses demokratisasi yang membutuhkan perhatian dari lebih banyak elemen bangsa, yaitu penegakan hukum, tata pamong yang baik, dan lain sebagainya masih gagal diterapkan sehingga pemerintahan yang demokratis pun cenderung merupakan pemerintahan yang korup karena mekanisme demokrasi tidak berjalan dengan baik. Indikasinya tentu dapat dengan mudah kita lihat dari makin menyebarnya modus dan pola korupsi yang berlangsung di hampir semua lini kehidupan politik dan pemerintahan yang menunjukkan gagalnya negara mengatur dan mendistribusikan kekuasaan untuk kepentingan rakyat.

Kedua, kegagalan proses demokrasi bisa jadi disebabkan belum siapnya pranata dan institusi politik, pemerintahan, dan ekonomi dengan sistem demokrasi itu sendiri. Dengan mengacu pada indikator-indikator awal yang diajukan Barro, kita dapat melihat bahwa meskipun sebagian anggota bangsa ini telah mengenyam taraf pendidikan yang memadai, namun sebagian besar masih berada pada situasi yang kurang menguntungkan. Termasuk juga di dalamnya kualitas kehidupan standar pada masyarakatnya yang masih sangat minimal, sehingga belum memungkinkan terjadinya partisipasi aktif dalam proses demokratisasi yang memberi peluang bagi peningkatan kualitas kehidupan.

Ketiga, pilihan demokrasi yang kurang sesuai dengan kemajemukan dan karakteristik bangsa. Akibatnya pola-pola penyaluran kehendak dan kepentingan rakyat selalu terbentur dengan oligarki partai politik di satu sisi dan berakibat pada terus meningkatnya tingkat golput, sebagai ketidak ikutsertaan rakyat dalam proses pemilihan, menunjukkan bahwa demokrasi yang berlangsung baru sebatas demokrasi elitis yang melibatkan sejumlah kecil pimpinan politik dan belum melibatkan rakyat secara keseluruhan. Akibatnya pilihan kebijakan yang dirumuskan antara ekskutif dan legislatif lebih merupakan kompromi politik untuk kepentingan para pimpinan partai politik dan belum mencerminkan kebutuhan rakyat akan kualitas perundangan yang memadai.

Jika kondisi-kondisi ini kita terima, maka dengan sendirinya proses pembangunan ekonomi nasional yang selama ini berlangsung sebenarnya belum merupakan buah dari proses demokratisasi yang juga sama-sama berlangsung, tapi baru merupakan 'pemanis kebijakan' yang dibuat baik oleh pemerintah maupun kompromi legislatif, semata-mata untuk kepentingan kekuasaan dan bukan untuk kepentingan rakyat. Ini berarti, proses demokratisasi yang sedang dibangun belum akan memberikan dampak maksimal bagi kehidupan ekonomi rakyat selama mekanisme demokrasi yang sebenarnya tidak diparaktekkan dan menjadi perhatian partai dan pemerintah.

Dengan kata lain, demokrasi yang riil belum benar-benar diterapkan dalam konteks politik Indonesia saat ini. Hanya dengan demokrasi yang benar-benar terlaksana dengan baik, rakyat mampu berpartisipasi dalam pembuatan dan pelaksanaan keputusan-keputusan yang mempengaruhi dirinya (Devine, 1995). Tanpa hal ini, maka demokrasi yang terjadi baru berupa demokrasi formal dan seremonial yang selain memakan banyak biaya, juga tidak menjamin 
terciptanya pemerintahan yang efektif. Pengalaman demokratisasi yang tengah berlangsung $\mathrm{di}$ Indonesia, secara jelas menunjukkan bagaimana demokrasi formal dan seremonial inilah yang mendominasi proses pengambilan keputusan yang berlangsung. Sebagaimana pernah ditulis Bung Hatta 'demokrasi dapat hidup dan kuat, kalau ada rasa tanggung djawab pada rakjat. Dengan tidak ada rasa tanggung djawab, tak mungkin ada demokrasi.' (Hatta, 1954:218)

\section{Langkah-langkah Strategik}

Kondisi lingkungan strategik di atas tentunya perlu mendapat perhatian semua pihak, terutama para pengambil keputusan. Pada tahap awal perubahan paradigma dalam mengelola kekuasaan jelas menjadi kunci utama. Paradigma pembangunan di masa lalu yang semata berorientasi pertumbuhan dan besaran makroekonomi terbukti gagal memberikan kontribusi penting bagi kepentingan nasional. Pertumbuhan ekonomi kita bisa jadi tinggi, stabilitas makroekonomi kita bisa jadi dipuji banyak pihak, namun hal tersebut tidak berarti apa-apa jika pada saat yang sama prestasi pemerintah dan capaian kesejahteraan rakyat jauh panggang dari api.

Etika berpolitik secara nasional harus direvitalisasi agar tidak hanya menjadi retorika tanpa implementasi. Sumber dari etika ini telah begitu banyak direkam dalam khazanah kebangsaan kita, mulai dari ajaran agama, pengalaman nenek moyang, adat istiadat, teladan para pendiri bangsa, dan pengalaman politik selama ini. Etika berpolitik harus dikedepankan dengan fokus terutama pada penanggulangan kartel politik, mafia hukum, dan mafia anggaran yang menghabiskan banyak sumber daya bangsa.

Peran politik dan ekonomi rakyat banyak juga perlu diperluas secara terpadu agar dapat menjadi penyeimbang kekuatan politik parpol dan menciptakan kemandirian di sisi lain. Rakyat harus semakin mudah menyampaikan kehendak politiknya secara bertanggung jawab agar kehendak mereka tidak diamputasi oleh wakil-wakil mereka yang kadang justru jauh dari aspirasi yang diharapkan. Peran ekonomi dapat diperluas dengan memberikan bantuan pembinaan pada unit-unit usaha yang dikelola oleh rakyat, dengan filosofi memberikan kail, bukan dengan memberikan bantuan tunai yang hanya akan mengurangi kemanndirian.

Keberanian pemerintah juga dituntut dalam menyikapi dampak globalisasi. Jika memang berkeras akan bertarung dengan bangsa lain dalam globalisasi ekonomi yang demikian cepat berkembang, maka upaya memberdayakan masyarakat agar dapat mandiri dan berkembang mutlak harus segera dilakukan. Sebaliknya jika memang dirasa gagal bersaing dengan bangsa lain, maka globalisasi harus dibatasi dan ditinjau ulang sebelum dampaknya betul-betul menghancurkan sendi-sendi kehidupan berbangsa. Tanpa sikap yang jelas, maka bangsa kita akan terus terombang-ambing antara cengkraman globalisasi yang kain menggurita dan kegagalan demokrasi di pihak lain.

\section{Kesimpulan}

Paparan di atas menunjukkan bahwa terdapat sejumlah permasalahan dalam dinamika bangsa terutama ditinjau dari sisi politik, hukum, ekonomi, sosial, dan budaya yang kesemuanya memerlukan solusi dalam waktu yang mendesak. Selain masalah dalam negeri, bangsa kita juga harus menghadapi gejolak internasional sebagai implikasi globalisasi yang lebih banyak membawa dampak negatif daripada dampak positif. Untuk itu, sejumlah langkah strategik diajukan untuk mengatasi masalah bangsa tersebut, diantaranya revitalisasi etika politik berbasis budaya bangsa, perubahan paradigma kebijakan nasional, dan peninjauan ulang keterlibatan dalam arus globalisasi. Langkah-langkah ini diperlukan agar bangsa kita mampu menyejajarkan diri dengan bangsa lain dalam percaturan global tanpa kehilangan jatidiri. 
Langkah Strategis Menghadapi Situasi Ekonomi-Politik Indonesia (Edi Suandi Hamid)

\section{Daftar Pustaka}

Badan Pusat Statistik (2012), Berita Resmi Statistik, No. 06/01/Th. XV, 2 Januari 2012.

Barro, Robert J., 1996. Democracy and Growth, Journal of Economic Growth, 1:1-27 (March 1996).

Bawono, Anton (2008), "Kerangka Kerja Aksioma Etika Ekonomi Islam". Ijtihad, Jurnal Wacana Hukum Islam dan Kemanusiaan, Vol. 8, No.1, Juni 2008, 57-69.

Callinicos, Alex (2003),An Anti-Capitalist Manifesto, Cambridge: Polity Press.

Fidrmuc, J. (2003) 'Economic Reform, Democracy and Growth During Post-Communist Transition', European Journal of Political Economy Vol. 19 (2003) 583-604.

Ginting, Darwin (2008), "Rekonstruksi Jati Diri Bangsa Indonesia dari Keterpurukan: Studi Analitikal dari Sisi Etika Hukum dan Filsafat Hukum Pancasila", Law Review, Volume 7, No. 3, Halaman 111-135.

Hamid, Edy Suandi (2004), Sistem Ekonomi, Utang Luar Negeri, dan Isyu-isyu Ekonomi Politik Indonesia, UII Press, Yogyakarta

Juoro, Umar, 2004, Demokrasi Membutuhkan Ekonomi. Kompas 3 September 2004.

Kaufmann, Kraay, dan Mastruzzi, 2008, Governance Matters VIl: Aggregate and Individual Governance Indicators 1996-2007, Policy Research Working Paper 4654. The World Bank Development Research Group Macroeconomics and Growth Team and World Bank Institute Global Governance Program June 2008.

Keraf, Sonny (1998),Etik Bisnis: Tuntutan dan Relevansinya. Yogyakarta: Kanisius.

Mahfud, Choirul (2008), "Etika Politik, Moralitas Publik dan Demokratisasi di Aras Lokal", Cakrawala: Jurnal Litbang Kebijakan, Volume 2, No. 2, Halaman 53-69.

Mutopadidjaja, A.R. (1997), "Tranformasi Manajemen Menghadapi Globalisasi Ekonomi", Jurnal Administrasi dan Pembangunan, Vol. 1, No. 1, Halaman 17.

Sudjana (2006), "Upaya Meningkatkan Standar Etika Organisasi Pemerintahan", Visioner: Jurnal Pemerintahan Daerah di Indonesia, Volume 2, No.:1, Halaman 81-97.

Yustika, Ahmad Erani, (20C4), Demokrasị Prasyarat Ekonomi? Kompas, 15 September 2004. 